\title{
Measuring Soil Nitrogen Mineralization under Field Conditions
}

\author{
K. S. Balkcom, ${ }^{1}$ A. M. Blackmer, ${ }^{2 *}$ and D. J. Hansen ${ }^{3}$ \\ ${ }^{1}$ U.S. Department of Agriculture-Agricultural Research Service, National Soil \\ Dynamics Laboratory, Auburn, Alabama, USA \\ ${ }^{2}$ Department of Agronomy, Iowa State University, Ames, Iowa, USA \\ ${ }^{3}$ Research and Education Center, University of Delaware, Georgetown, \\ Delaware, USA
}

\begin{abstract}
Land application of animal manure is known to alter rates of nitrogen (N) mineralization in soils, but quantitative information concerning intensity and duration of these effects has been difficult to obtain under field conditions. We estimated net effects of manure on $\mathrm{N}$ mineralization in soils under field conditions in a completely randomized design, at six field sites, by comparing liquid swine (Sus scrofa) manure treatments to plots receiving no manure. Soil samples were collected immediately after manure application to determine inorganic $\mathrm{N}$ concentrations, and those samples were also incubated $28 \mathrm{~d}$ in the laboratory to determine amounts of $\mathrm{N}$ mineralized from the soil. Analyses and incubation were repeated on a second set of samples collected after various times, depending on the site. Differences in inorganic $\mathrm{N}$ concentrations were significant among treatments at all six locations for the first sampling and five of the six locations for the second sampling. In comparison, significant differences in inorganic $\mathrm{N}$ concentrations measured after $28 \mathrm{~d}$ of laboratory incubation were observed for only two of the six sites for each sampling time. Our results illustrate how to distinguish between the effects manure has on rates of $\mathrm{N}$ mineralization in soils and rates at which manure $\mathrm{N}$ is mineralized.
\end{abstract}

Keywords: Dribbled, injected, swine manure

* deceased

Received 30 April 2007, Accepted 8 September 2007

Address correspondence to K. S. Balkcom, USDA-ARS, National Soil Dynamics Laboratory, 411 S. Donahue Dr., Auburn, AL 36832, USA. E-mail: kip.balkcom@ars.usda.gov 


\section{INTRODUCTION}

Land application of animal manures can supply nitrogen $(\mathrm{N})$ for crop growth, but much of the $\mathrm{N}$ in manure is organically bound and must be mineralized (i.e., converted to inorganic forms) before it is available to plants. Information concerning rates of $\mathrm{N}$ mineralization is needed to estimate amounts of $\mathrm{N}$ that a given application will supply for a succeeding crop. Currently, estimated rates often are given as decay series, first described by Pratt, Broodbent, and Martin (1973) and Pratt, Davis, and Sharpless (1976), which indicate amounts of N likely to be supplied within various time periods (usually years) after manure is applied. Although decay series often are used in guidelines for animal manure application, quantitative methods for experimentally developing or testing the accuracy of a decay series have never been described. This is a problem because it is reasonable to expect that decay series vary significantly with factors such as methods of manure storage, manure composition, and regional differences in soil temperature and moisture.

Another problem is that additions of organic materials are known to promote $\mathrm{N}$ immobilization (i.e., conversion of inorganic to organic forms) as well as mineralization of N. Organic compounds with relatively high carbon (C) to $\mathrm{N}$ ratios tend to stimulate immobilization more than mineralization of $\mathrm{N}$ until the "turning point" occurs, and then mineralization is more prevalent than immobilization (Jenkinson 1981). Although less easy to detect, immobilization also accompanies mineralization when organic compounds with relatively low $\mathrm{C}$ to $\mathrm{N}$ ratios decompose in soils. The processes involved have been discussed in many reviews (Black 1968; Allison 1973; Jenkinson 1981; Jansson and Persson 1982; Jenkinson, Fox, and Rayner 1985; Schepers and Mosier 1991; Powlson and Barraclough 1993). Recent studies (Blackmer and Green 1995; Green and Blackmer 1995; Green, Blackmer, and Horton 1995) illustrate the importance of adequately distinguishing between amounts of $\mathrm{N}$ mineralized from organic materials and effects of organic materials on net amounts of $\mathrm{N}$ mineralization within any given period.

The net effects of manure on rates of $\mathrm{N}$ mineralization in soils can be studied under laboratory conditions by comparing rates of inorganic $\mathrm{N}$ accumulation in samples with and without added manure (Flowers and Arnold 1983; Sims 1986; Bitzer and Sims 1988; Bernal and Kirchmann 1992). Such studies can reveal how rates of $\mathrm{N}$ mineralization vary with soil conditions and characteristics of manure under controlled conditions. As noted by Flowers and Arnold (1983), however, such studies cannot be expected to give reliable estimates of effects of manure on mineralization rates in soil under field conditions, where many factors are continuously changing with time. 
Field studies can provide important information about effects of manure applications on measurable factors such as soil nitrate $\left(\mathrm{NO}_{3}-\mathrm{N}\right)$ concentration, crop yield, and soil organic-matter concentration (Magdoff 1978; King 1984; Klausner, Kanneganti, and Bouldin 1994). However, such studies do not provide reliable estimates of net effects of manure on $\mathrm{N}$ mineralization in soil because effects of $\mathrm{N}$ mineralization are confounded with effects of several other processes that cannot be controlled under field conditions. These processes include mineralization of $\mathrm{N}$ from organic materials that were in the soil before manure was applied; losses of $\mathrm{N}$ from soil by ammonia volatilization, leaching and denitrification; and plant uptake of N. Additions of manure can affect all of these processes simultaneously, and the magnitude of each effect varies with interactions between manure characteristics and soil conditions.

In view of these problems, it seems reasonable to conclude that there is no practical experimental method for measuring net effects of manure on $\mathrm{N}$ mineralization in soils under specific field conditions. Rather than try to directly measure effects of manure on mineralization rates in soil, it may be more practical to measure the potential importance of these combined effects at various times after manure is applied. Therefore, the objective of this study was to estimate net effects of liquid swine manure on soil $\mathrm{N}$ mineralization under field conditions with an approach that combines field and laboratory techniques.

\section{MATERIALS AND METHODS}

Field trials containing replicated plots ( $15 \mathrm{~m}$ long, $4.6 \mathrm{~m}$ wide) with and without liquid swine manure were established at six sites in Iowa between May 1996 and May 1998. Three sites were located at the Agronomy and Agricultural Engineering Research Center near Ames, Iowa, and three were located at the Northern Research and Demonstration Center near Kanawha, Iowa. Soils at the sites were mapped as either Canisteo clay loam (fine-loamy, mixed, superactive, calcareous, mesic Typic Endoaquolls), Clarion loam (fine-loamy, mixed, superactive, mesic Typic Hapludolls), or Nicollet clay loam (fine-loamy, mixed, superactive, mesic Aquic Hapludolls).

Three treatments were applied in a completely randomized design with four replications; liquid swine manure injected to a depth of 5-10 cm in $30-\mathrm{cm}$ bands, liquid swine manure dribbled on the surface in $30-\mathrm{cm}$ bands without incorporation, and a control receiving no manure. Liquid swine manure was collected from production units typical to Iowa. The manure included all urine generated by the animals. Manure was continuously added to pits that were emptied once or twice each year, so organic compounds in the manure decomposed under anaerobic 
conditions for various amounts of time. Manure in the pits was agitated before it was pumped into tanks of land applicators. Samples of manure applied at each site were collected and analyzed for total $\mathrm{N}$ (Kjeldahl), ammonium $\left(\mathrm{NH}_{4}-\mathrm{N}\right)$, and total solids using methods described by Hach (1988) and APHA (1995). Rates and dates of manure application and sampling times for each site are shown in Table 1. All plots were conventionally tilled and managed by practices normally used for corn (Zea mays L.) production in Iowa.

Soil samples were collected two times from each plot to a depth of $30 \mathrm{~cm}$ after manure application. The first set of samples was collected from each plot as soon as soil conditions permitted, because of sampling problems caused by water in the manure. A second set of samples was collected early in the growing season of the corn crop, usually just before corn needed $\mathrm{N}$ to support rapid growth in June, July, and August. The length of time between the first and second sampling times varied depending on whether the manure was applied in fall or spring. Time between the first and second samples was $169 \mathrm{~d}$ for site 3, which received manure in the fall, and averaged $50 \mathrm{~d}$ at the remaining sites where manure was applied in the spring.

Each soil sample was a composite of 40 cores $(1.7-\mathrm{cm}$ diam.) from each plot. The cores were collected as five sets of eight cores, where the individual cores in each set were evenly spaced along $30-\mathrm{cm}$ transects located perpendicular to the bands of manure application and approximately centered on a band. Manure was applied at each site prior to planting corn between late April and the middle of May each year.

Soil samples were stored at $-20{ }^{\circ} \mathrm{C}$ until analyses, and then the samples were thawed and sieved (2-mm mesh) in the field-moist condition. Forty-g subsamples of each sample were placed in five flasks having a volume of $1.5 \mathrm{~L}$ and a ground-glass joint at the top. Each flask was sealed with a top consisting of a ground-glass joint and a glass

Table 1. Rates and dates of manure application and dates soil samples were collected for six sites in Iowa

\begin{tabular}{llrcrr}
\hline Site & Soil type & $\begin{array}{c}\text { Date of } \\
\text { application }\end{array}$ & $\begin{array}{c}\text { Rate of application } \\
\left(\mathrm{kL} \mathrm{ha}^{-1}\right)\end{array}$ & $\begin{array}{c}\text { First } \\
\text { sampling }\end{array}$ & $\begin{array}{c}\text { Second } \\
\text { sampling }\end{array}$ \\
\hline $1(\mathrm{~K})^{a}$ & Nicollet loam & $5-5-98$ & 38 & $5-8-98$ & $6-22-98$ \\
$2(\mathrm{~K})$ & Clarion loam & $5-6-96$ & 17 & $5-16-96$ & $6-27-96$ \\
$3(\mathrm{~A})$ & Clarion loam & $10-30-97$ & 57 & $11-5-97$ & $4-23-98$ \\
$4(\mathrm{~K})$ & Clarion loam & $4-24-97$ & 19 & $5-2-97$ & $6-5-97$ \\
$5(\mathrm{~A})$ & Clarion loam & $4-15-97$ & 46 & $4-18-97$ & $6-5-97$ \\
$6(\mathrm{~A})$ & Canisteo loam & $4-22-98$ & 68 & $4-24-98$ & $7-16-98$ \\
\hline
\end{tabular}

${ }^{a}$ Kanawha or Ames location. 
stopcock (1-mm-diam. bore). All bottles were placed in an incubator at $30{ }^{\circ} \mathrm{C}$. One flask for each soil sample was analyzed after $0,7,14,21$, and $28 \mathrm{~d}$ of incubation. Day 0 corresponds to the initial inorganic $\mathrm{N}$ concentrations measured in the field for each sample time.

Mineralization of $\mathrm{N}$ during laboratory incubations was examined by measuring accumulations of $\mathrm{NO}_{3}-\mathrm{N}$ and extractable $\mathrm{NH}_{4}-\mathrm{N}$. These were determined by adding $200 \mathrm{~mL}$ of $1 \mathrm{~N}$ potassium chloride $(\mathrm{KCl})$ to each flask, shaking the flasks to form a suspension, filtering, and analyzing the filtrate by steam distillation with magnesium oxide $(\mathrm{MgO})$ and Devarda's alloy as described by Keeney and Nelson (1982). The amount of $\mathrm{N}$ mineralized after $28 \mathrm{~d}$ of incubation was calculated by subtracting amounts of $\mathrm{NO}_{3}-\mathrm{N}$ and extractable $\mathrm{NH}_{4}-\mathrm{N}$ present at the start of the incubation from amounts found at the end of the incubation.

Data were analyzed by analyses of variance using a general linear model procedure provided by Statistical Analysis System (1996). Separate analyses of variance were computed for each site. Treatment differences were considered significant when $\mathrm{P}>\mathrm{F}$ was equal to, or less than, 0.05 . Orthogonal contrast statements were used to further distinguish treatment differences.

\section{RESULTS AND DISCUSSION}

\section{Manure Composition}

Analyses indicated that concentrations of total $\mathrm{N}$ in the manure ranged from 2.0 to $6.5 \mathrm{~g} \mathrm{~L}^{-1}$ (165 to $249 \mathrm{~g} \mathrm{~N} \mathrm{~kg}^{-1}$ dry matter), and organic $\mathrm{N}$ accounted for 14 to $77 \%$ of this $\mathrm{N}$ (Table 2). These analyses support earlier observations (Hatfield, Brumm, and Melvin 1998) that liquid swine manure is highly variable in $\mathrm{N}$ concentration and percentage of organic $\mathrm{N}$. This variability makes it very difficult to conduct studies where identical treatments are applied across several sites; however, the

Table 2. Analyses of liquid swine manure applied at six sites in Iowa

\begin{tabular}{lccc}
\hline Site & \multicolumn{3}{c}{ Amounts applied } \\
\cline { 2 - 4 } & Total solids $\left(\mathrm{kg} \mathrm{ha}^{-1}\right)$ & $\mathrm{NH}_{4}-\mathrm{N}\left(\mathrm{kg} \mathrm{ha}^{-1}\right)$ & Organic-N $\left(\mathrm{kg} \mathrm{ha}^{-1}\right)$ \\
\hline $1(\mathrm{~K})^{a}$ & 1493 & 57 & 189 \\
$2(\mathrm{~K})$ & 850 & 28 & 41 \\
$3(\mathrm{~A})$ & 913 & 105 & 45 \\
$4(\mathrm{~K})$ & 188 & 33 & 11 \\
$5(\mathrm{~A})$ & 448 & 69 & 23 \\
$6(\mathrm{~A})$ & 571 & 122 & 20 \\
\hline
\end{tabular}

${ }^{a}$ Kanawha or Ames location. 
variability encountered would be analogous to variability producers encountered in their operations.

Analyses revealed no useful relationships between calculated rates of manure $\mathrm{N}$ application and amounts of manure $\mathrm{N}$ recovered in the soil (data not shown). Inorganic $\mathrm{N}$ concentrations measured at the first sampling (Table 3) were excessive for sites 1, 2, 4, and 5 based on the calculated rates of inorganic $\mathrm{N}$ supplied by each manure application (Table 2). Recovery values were higher if only plots receiving injected applications of manure were considered. Such high recoveries of $\mathrm{N}$ usually are not encountered following applications of commercially prepared fertilizers (Binford, Blackmer, and Cerrato 1992; Morris, Blackmer, and El-Hout 1993).

Difficulties associated with sampling, analyzing, and/or applying manure may explain the high recoveries observed at some sites. A sample collected for laboratory analysis, as tanks were filled, may not accurately represent what was applied, because liquid swine manure is primarily a suspension, with organic matter present primarily as solids that settle rapidly. Problems caused by variability in manure composition have been described (Sutton 1992), and they must be expected in research field studies that are attempting to mimic current production agriculture practices. Rapid mineralization of some of the organic $\mathrm{N}$ could contribute to the high recoveries observed, but these recoveries of $\mathrm{N}$ also support the conclusion that exact analysis of manure would not be

Table 3. Initial inorganic $\mathrm{N}$ concentrations measured in the field from control (C), dribbled (D), and injected (I) treatments at two different sample times (values in parentheses are standard errors, $\mathrm{n}=4$ )

\begin{tabular}{|c|c|c|c|c|c|c|}
\hline \multirow[t]{2}{*}{$\begin{array}{l}\text { Sample } \\
\text { time }\end{array}$} & \multirow[t]{2}{*}{ Site } & \multicolumn{3}{|c|}{$\begin{array}{l}\text { Treatment } \\
\left(\mathrm{mg} \mathrm{kg}^{-1}\right)\end{array}$} & \multicolumn{2}{|c|}{$\begin{array}{c}\text { Contrast statements } \\
\qquad(\mathrm{P}>\mathrm{F})\end{array}$} \\
\hline & & Control & Dribbled & Injected & C-vs-D and $\mathrm{I}^{a}$ & D-vs-I \\
\hline \multirow[t]{6}{*}{1} & 1 & $3.6(0.2)$ & $31.9(1.8)$ & $34.1(2.7)$ & $<0.0001$ & 0.4316 \\
\hline & 2 & $8.3(1.2)$ & $19.2(1.7)$ & $21.6(4.4)$ & 0.0062 & 0.5512 \\
\hline & 3 & $4.7(1.3)$ & $16.0(3.0)$ & $42.3(11.0)$ & 0.0146 & 0.0202 \\
\hline & 4 & $5.1(0.5)$ & $14.8(2.2)$ & $16.6(1.2)$ & 0.0003 & 0.4205 \\
\hline & 5 & $7.4(0.01)$ & $20.5(4.1)$ & $34.7(6.2)$ & 0.0113 & 0.0587 \\
\hline & 6 & $4.3(0.6)$ & $16.2(3.3)$ & $25.7(3.0)$ & 0.0006 & 0.0296 \\
\hline \multirow[t]{6}{*}{2} & 1 & $6.0(0.5)$ & $28.6(0.8)$ & $35.9(2.0)$ & $<0.0001$ & 0.0028 \\
\hline & 2 & $7.9(1.1)$ & $18.2(1.6)$ & $20.3(3.9)$ & 0.0053 & 0.5671 \\
\hline & 3 & $3.1(0.4)$ & $7.2(1.1)$ & $20.0(5.0)$ & 0.0180 & 0.0140 \\
\hline & 4 & $8.4(1.0)$ & 33.5 (4.9) & $32.0(4.2)$ & 0.0005 & 0.7915 \\
\hline & 5 & $8.0(0.6)$ & $14.9(0.9)$ & $27.5(2.1)$ & $<0.0001$ & 0.0001 \\
\hline & 6 & $3.7(0.5)$ & $3.9(0.5)$ & $6.9(1.2)$ & 0.1223 & 0.0260 \\
\hline
\end{tabular}

${ }^{a} \mathrm{C}$, control; D, dribbled; I, injected. 
helpful. Regardless, this observation highlights a concern regarding the value of analyses that distinguish between organic and inorganic forms of $\mathrm{N}$, assuming that our sampling methods were as reliable as those normally used in production agriculture.

Nitrogen losses before mineralization-immobilization processes occur in soils diminish knowledge obtained on exact amounts and forms of manure $\mathrm{N}$ that leave the manure applicator. Loss of inorganic $\mathrm{N}$ by ammonia volatilization during application, for example, could substantially alter the net effects of manure on amounts of $\mathrm{N}$ mineralized in soil during any given period. However, knowledge of amounts of ammonia volatilized alone would be of little help if losses associated with leaching were not accounted for, because this process could also alter the net effects of manure on amounts of $\mathrm{N}$ mineralized in soil during any given period.

\section{Nitrogen Mineralization}

Inorganic $\mathrm{N}$ concentrations measured from field plots receiving manure were significantly different from the control for all six locations at the first sampling (Table 3). Of the six field sites where differences were detected, sites 3 and 6 revealed that inorganic $\mathrm{N}$ concentrations measured from plots receiving injected applications of manure were greater than plots receiving dribbled applications of manure. These findings suggest that $\mathrm{N}$ losses through ammonia volatilization may have occurred from plots receiving manure by the dribbled method of application. Nitrogen losses by ammonia volatilization can be substantial when manure is not immediately incorporated into the soil (Hoff, Nelson, and Sutton 1981).

At the second sampling, inorganic $\mathrm{N}$ concentrations measured in the field were different for five of the six sites (Table 3), with sites 1,3 , and 5 revealing a difference between injected manure and dribbled manure applications. Site 6 also revealed higher concentrations of inorganic N measured in plots receiving injected manure compared to plots receiving dribbled manure, even though no differences were detected between plots receiving manure and plots not receiving manure. The lower inorganic $\mathrm{N}$ concentrations measured at site 6 for the second sampling may have resulted from plant uptake because the sampling date was 2 weeks past the period that corn plants begin rapid $\mathrm{N}$ uptake. These observations indicate that the sampling methods used were adequate to detect important effects of manure treatments on concentrations of inorganic $\mathrm{N}$ in plots. These findings also indicate that amounts of inorganic $\mathrm{N}$ (and possibly some organic $\mathrm{N}$ that was mineralized very rapidly) supplied by manure exceeded background levels of inorganic $\mathrm{N}$ in soils (Table 3 ). 
Significant differences were observed in inorganic $\mathrm{N}$ concentrations measured after $28 \mathrm{~d}$ of incubation for the first sampling at sites 2 and 4; similar trends were observed at sites 1 and 3 (Table 4). At the second sampling, increases in inorganic $\mathrm{N}$ concentrations measured after $28 \mathrm{~d}$ of incubation were significant at sites 1 and 2. No differences between methods of application were detected among sites for either sample time. Inorganic $\mathrm{N}$ concentrations measured after $28 \mathrm{~d}$ of laboratory incubation provided evidence of $\mathrm{N}$ immobilization at sites 5 and 6 for the first sample time, as a result of manure applications. The second sampling provided evidence of $\mathrm{N}$ immobilization at site 3 , in addition to more evidence that $\mathrm{N}$ immobilization occurred at sites 5 and 6 .

The findings observed on amounts of $\mathrm{N}$ mineralized after $28 \mathrm{~d}$ of incubation are noteworthy because incubations were conducted under ideal conditions; the amounts mineralized under these conditions should be expected to exceed amounts mineralized during the remainder of the growing season under field conditions (Green and Blackmer 1995). These findings indicate that potential effects of mineralization of $\mathrm{N}$ from the organic fraction of manure usually were much less than observed increases of inorganic $\mathrm{N}$ concentrations resulting from manure applications.

When only means across sites were considered, temporal patterns in $\mathrm{N}$ mineralization during laboratory incubations (Figure 1) showed that mineralization of $\mathrm{N}$ from soil receiving manure continued throughout the

Table 4. Amounts of inorganic $\mathrm{N}$ formed during $28 \mathrm{~d}$ of incubation from soil samples collected from control (C), dribbled (D), and injected (I) treatments at two different sample times (values in parentheses are standard errors, $n=4$ )

\begin{tabular}{|c|c|c|c|c|c|c|}
\hline \multirow[t]{2}{*}{$\begin{array}{l}\text { Sample } \\
\text { time }\end{array}$} & \multirow[t]{2}{*}{ Site } & \multicolumn{3}{|c|}{$\begin{array}{l}\text { Treatment } \\
\left(\mathrm{mg} \mathrm{kg}^{-1}\right)\end{array}$} & \multicolumn{2}{|c|}{$\begin{array}{c}\text { Contrast statements } \\
\qquad(\mathrm{P}>\mathrm{F})\end{array}$} \\
\hline & & Control & Dribbled & Injected & C-vs-D and $\mathrm{I}^{a}$ & D-vs-I \\
\hline \multirow[t]{6}{*}{1} & 1 & $5.4(0.3)$ & $10.4(1.4)$ & $10.3(3.0)$ & 0.0635 & 0.9800 \\
\hline & 2 & $19.8(2.4)$ & 37.7 (7.8) & $57.7(10.6)$ & 0.0165 & 0.1022 \\
\hline & 3 & $14.7(2.5)$ & $24.7(4.1)$ & $30.7(7.2)$ & 0.0628 & 0.4154 \\
\hline & 4 & $12.8(0.3)$ & $26.0(3.5)$ & $23.8(4.9)$ & 0.0194 & 0.6538 \\
\hline & 5 & $17.3(1.5)$ & $16.4(1.9)$ & $13.7(2.5)$ & 0.3718 & 0.3677 \\
\hline & 6 & $17.8(2.4)$ & $18.7(0.9)$ & $16.3(1.5)$ & 0.8948 & 0.3345 \\
\hline \multirow[t]{6}{*}{2} & 1 & $9.4(0.3)$ & $15.2(0.9)$ & $14.4(0.3)$ & $<0.0001$ & 0.3599 \\
\hline & 2 & $13.9(2.3)$ & $20.4(1.4)$ & $21.5(1.9)$ & 0.0136 & 0.6798 \\
\hline & 3 & $9.1(1.0)$ & $9.3(0.7)$ & $8.5(1.9)$ & 0.9070 & 0.6735 \\
\hline & 4 & $12.2(0.5)$ & $20.7(2.2)$ & $25.5(9.2)$ & 0.1373 & 0.5437 \\
\hline & 5 & $14.6(0.9)$ & $13.8(0.4)$ & $12.5(1.5)$ & .2780 & 0.3973 \\
\hline & 6 & $12.6(0.7)$ & $12.0(1.5)$ & $12.2(1.3)$ & 0.7770 & 0.8973 \\
\hline
\end{tabular}

${ }^{a} \mathrm{C}$, control; D, dribbled; I, injected. 


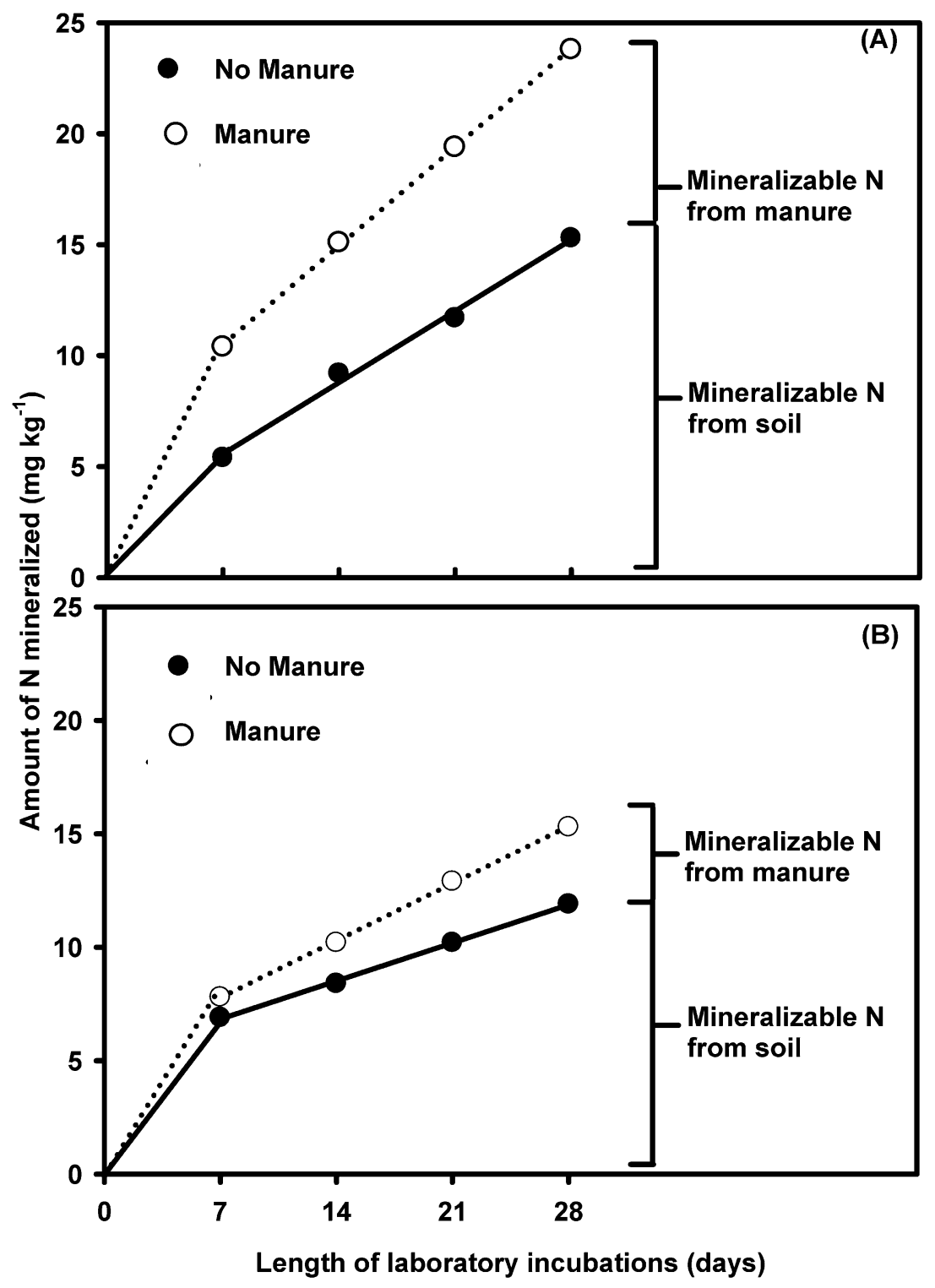

Figure 1. Amounts of inorganic $\mathrm{N}$ mineralized $\left(\mathrm{mg} \mathrm{N} \mathrm{kg}^{-1}\right.$ soil) from soils incubated with and without liquid swine manure from the first (A) and second (B) sampling time averaged over six locations in Iowa.

28-d incubations (i.e., the lines continued to diverge in Figure 1A). This observation indicates that manure still had detectable effects on $\mathrm{N}$ mineralization rates under field conditions. By the second sampling, which corresponds to when corn begins rapid uptake of $\mathrm{N}$, the effects of 
manure on amounts of $\mathrm{N}$ mineralized in the laboratory were less than half the background mineralization rates in soil (Figure 1B). If methods with adequate sensitivity were used, the effects probably could be detected for years to come. Such observations, however, do not alter the conclusion that effects of manure on $\mathrm{N}$ mineralization rapidly became too small to be of practical importance.

It should be noted that analyses based on means across sites can mask important variability among sites. An advantage of our approach is the ability to detect this variability. Soil and environmental conditions will vary from site to site and cannot be controlled in the field as in the laboratory, which affects amounts of $\mathrm{N}$ mineralized at a particular site. The need to consider variability among sites is shown by the finding that the net effect of manure was to induce immobilization of $\mathrm{N}$ at sites 3,5, and 6 during incubation of soils for the second sampling (Table 4). Such an effect should be expected if manure contained some material with a relatively high $\mathrm{C}$-to- $\mathrm{N}$ ratio that tended to dominate $\mathrm{N}$ immobilizationmineralization activities during a period after the immediate effects of manure were expressed. For example, undecomposed fragments of feed for swine (e.g., corn grain) should be expected to have high C-to-N ratios, and decomposition of these materials could promote net immobilization of $\mathrm{N}$.

Our approach also allows a direct comparison of the effects different application methods have on amounts of $\mathrm{N}$ mineralized. Surface-applied or incorporated application methods can be simulated in the laboratory, but environmental conditions across field sites and their effects on $\mathrm{N}$ mineralization cannot be easily simulated. For example, no differences were found between methods of application in inorganic $\mathrm{N}$ concentrations for sample time 1 at site 1; however, by the second sample time, significant differences were observed between methods of application (Table 3). In contrast, no differences were detected between methods of application at site 4 for either sample time, but inorganic $\mathrm{N}$ concentrations measured at the second sample time were much higher, indicating $\mathrm{N}$ mineralization in the field between sample times. Although times and rates of application were different for these two sites, the results demonstrate how this approach may help determine how manure affects $\mathrm{N}$ mineralization of soil under specific field conditions. Laboratory studies are assumed to assess only the potential importance of mineralization because an effect observed in the laboratory may not be observed in the field. For example, soil perturbation associated with sampling and mixing, as well as a uniform incubation temperature, could cause $\mathrm{N}$ mineralization to proceed much more rapidly in the laboratory than it would in the field.

Results of this study show that net effects of liquid swine manure on supplies of inorganic $\mathrm{N}$ for plant growth measured in the field were much 
more important than net effects of this manure on rates of $\mathrm{N}$ mineralization measured after $28 \mathrm{~d}$ of incubation. This finding can be explained by recognizing that substantial portions of $\mathrm{N}$ in manure were present as $\mathrm{NH}_{4}-\mathrm{N}$ and that those organic compounds most susceptible to microbial degradation probably degraded during storage in the pit. Liquid swine manure used in this study essentially had an inorganic $\mathrm{N}$ fraction that behaved like a commercial fertilizer and an organic $\mathrm{N}$ fraction that was relatively inert.

The results of this study should not be considered evidence that cumulative effects of many applications of liquid swine manure are unimportant. Abundant evidence suggests that much of the $\mathrm{C}$ and $\mathrm{N}$ in organic materials added to soils remains for years and slightly increases rates of $\mathrm{N}$ mineralization of soils. Subsequent soil samplings could be used to measure cumulative net effects of successive applications of liquid swine manure on $\mathrm{N}$ mineralization rates in soils. It needs to be recognized, however, that for annual crops that receive liquid swine manure, such as corn, it may be more practical and informative to simply measure net effects of these applications on concentrations of inorganic $\mathrm{N}$ in soil when crops begin rapid uptake of $\mathrm{N}$ to support crop growth. Previous research has documented the success of such an approach for corn production (Magdoff, Ross, and Amadon 1984; Magdoff 1991).

The rates at which organic $\mathrm{N}$ from manure is mineralized must always be positive and should be expected to gradually decrease with time. Commonly used decay series (Pratt, Broodbent, and Martin 1973; Pratt, Davis, and Sharpless 1976) seem to follow such a pattern, but methods used to calculate decay rates have never been explained. It is essentially impossible to measure rates at which organic $\mathrm{N}$ is mineralized in soils, and information concerning these rates has little practical value. The net effects of manure on $\mathrm{N}$ mineralization, however, can be much more complex and vary with the composition of organic compounds in manure. The net effects of manure on rates of mineralization can be either negative or positive during any given time during decomposition of manure. The net effect of manure on $\mathrm{N}$ mineralization, therefore, can either decrease or increase supplies of inorganic $\mathrm{N}$ for growth of a given crop. Although the net effects on $\mathrm{N}$ mineralization may follow a predictable pattern with respect to percentage decomposition of manure, percentage decomposition at any given time varies with site conditions and is essentially unknown under field conditions.

Therefore, these studies were initiated with the assumption that the potential importance of $\mathrm{N}$ mineralization at any given time could be measured through laboratory incubation studies that quantify differences in $\mathrm{N}$ mineralization rates between samples from plots with and without a manure application. Large differences in mineralization rates would indicate effects of manure were still important, and no detectable 
differences in rates would indicate that effects were too small to be of practical importance. Field and incubation measurements on samples collected at selected times after manure application would reveal the temporal pattern in effects of manure on $\mathrm{N}$ mineralization at different sites. The proposed samples would also reveal how long the effects of manure should be considered important amid normal variability in supplies of inorganic $\mathrm{N}$ and background rates of $\mathrm{N}$ mineralization in soils.

\section{CONCLUSIONS}

Measurements in these experiments were made across a range of conditions selected to be representative of those found when liquid swine manure is applied as an $\mathrm{N}$ source for corn production in Iowa. The results of this study indicate the need to clearly distinguish among (i) rates at which organic $\mathrm{N}$ from manure is mineralized, (ii) net effects of manure on rates of $\mathrm{N}$ mineralization in soils, and (iii) net effects of manure on supplies of inorganic $\mathrm{N}$ when plants are growing. Future studies utilizing this approach could examine how $\mathrm{N}$ mineralization is affected by various types of animal manure, methods of application, or methods of manure storage.

The net effects of animal manure on $\mathrm{N}$ mineralization in soils during any period (i.e., for any given crop) can be measured by laboratory analyses of soil samples collected from field plots with and without added manure. Rates of $\mathrm{N}$ mineralization observed under laboratory conditions reveal differences due to manure treatments applied in the field. The potential importance of these differences can be evaluated through comparisons with background rates of $\mathrm{N}$ mineralization and effects of manure on concentrations of inorganic $\mathrm{N}$ under field conditions.

Although the sites in this experiment were intended to provide information about measuring net effects of manure on $\mathrm{N}$ mineralization in soils, the results observed under these environmental conditions with liquid swine manure clearly illustrate the importance of methods, such as soil testing, which can measure the net effect of manure on supplies of inorganic $\mathrm{N}$ present when plants begin rapid growth.

\section{REFERENCES}

Allison, F. E. 1973. Soil organic matter and its role in crop production. Amsterdam, Denmark: Elsevier Scientific Publishing Company.

American Public Health Association (APHA). 1995. Standard methods for the examination of waters and wastewaters, 19th ed. Washington, D.C.: APHA.

Bernal, M. P., and H. Kirchmann. 1992. Carbon and nitrogen mineralization and ammonia volatilization from fresh, aerobically and anaerobically treated 
pig manure during incubation with soil. Biology and Fertility of Soils 13:135141.

Binford, G. D., A. M. Blackmer, and M. E. Cerrato. 1992. Relationships between corn yields and soil nitrate in late spring. Agronomy Journal 84:53-59.

Bitzer, C. C., and J. T. Sims. 1988. Estimating the availability of nitrogen in poultry manure through laboratory and field studies. Journal of Environmental Quality 17:47-54.

Black, C. A. 1968. Soil-plant relationships. New York: Wiley.

Blackmer, A. M., and C. J. Green. 1995. Nitrogen turnover by sequential immobilization and mineralization during residue decomposition in soils. Soil Science Society of America Journal 59:1052-1058.

Flowers, T. H., and P. W. Arnold. 1983. Immobilization and mineralization of nitrogen in soils incubated with pig slurry or ammonium sulphate. Soil Biology and Biochemistry 15:329-335.

Green, C. J., and A. M. Blackmer. 1995. Residue decomposition effects on nitrogen availability to corn following corn or soybean. Soil Science Society of America Journal 59:1065-1070.

Green, C. J., A. M. Blackmer, and R. Horton. 1995. Nitrogen effects on conservation of carbon during corn residue decomposition in soil. Soil Science Society of America Journal 59:453-459.

Hach Company. 1988. Chemical analysis. In Soil testing in common regional extractants, 58-66. Loveland, Col.: Hach Company.

Hatfield, J. L., M. C. Brumm, and S. W. Melvin. 1998. Swine manure management. In Agricultural uses of municipal, animal, and industrial byproducts (Research Report No.44), ed. R. J. Wright, 78-90. Washington, D.C.: USDA.

Hoff, J. D., D. W. Nelson, and A. L. Sutton. 1981. Ammonia volatilization from liquid swine manure applied to cropland. Journal of Environmental Quality 10:90-95.

Jansson, S. L., and J. Persson. 1982. Mineralization and immobilization of soil nitrogen. In Nitrogen in agricultural soils, ed. F. J. Stevenson, 229-252. Madison, Wisc.: ASA, CSSA, and SSSA.

Jenkinson, D. S. 1981. The fate of plant and animal residues in soil. In The chemistry of soil processes, ed. D. J. Greenland and M. H. B. Hayes, 505-561. New York: John Wiley \& Sons.

Jenkinson, D. S., R. H. Fox, and J. H. Rayner. 1985. Interactions between fertilizer nitrogen and soil nitrogen-The so-called "Priming" effect. Journal of Soil Science 36:425-444.

Keeney, D. R., and D. W. Nelson. 1982. Nitrogen-Inorganic forms. In Methods of soil analysis, part 2, 2nd ed., ed. A. L. Page, R. H. Miller, and D. R. Keeney, 643-698. Madison, Wisc.: ASA and SSSA.

King, L. D. 1984. Availability of nitrogen in municipal, industrial, and animal wastes. Journal of Environmental Quality 13:609-612.

Klausner, S. D., V. R. Kanneganti, and D. R. Bouldin. 1994. An approach for estimating a decay series for organic nitrogen in animal manure. Agronomy Journal 86:897-903.

Magdoff, F. R. 1978. Influence of manure application rates and continuous corn on soil-N. Agronomy Journal 70:629-632. 
Magdoff, F. 1991. Understanding the Magdoff pre-sidedress nitrate test for corn. Journal of Production Agriculture 4:297-305.

Magdoff, F. R., D. Ross, and J. Amadon. 1984. A soil test for nitrogen availability to corn. Soil Science Society of America Journal 48:1301-1304.

Morris, T. F., A. M. Blackmer, and N. M. El-Hout. 1993. Optimal rates of nitrogen fertilization for first-year corn after alfalfa. Journal of Production Agriculture 6:344-350.

Powlson, D. S., and D. Barraclough. 1993. Mineralization and assimilation in soil-plant systems. In Nitrogen isotope techniques, ed. R. Knowles, and T. H. Blackburn, 209-242. San Diego, Calif.: Academic Press.

Pratt, P. F., F. E. Broodbent, and J. P. Martin. 1973. Using organic wastes as nitrogen fertilizers. California Agriculture 27:10-13.

Pratt, P. F., S. Davis, and R. G. Sharpless. 1976. A four-year field trial with manures. Hilgardia 44:99-125.

SAS Institute. 1996. The SAS system for Windows, release 6.12. Cary, N.C.: SAS Institute.

Schepers, J. S., and A. R. Mosier. 1991. Accounting for nitrogen in nonequilibrium soil-crop systems. In Managing nitrogen for groundwater quality and farm profitability, ed. R. F. Follet, D. R. Kenney, and R. M. Cruse, 125-128. Madison, Wisc.: SSSA.

Sims, J. T. 1986. Nitrogen transformations in a poultry manure amended soil: Temperature and moisture effects. Journal of Environmental Quality 15:59-63.

Sutton, A. L. 1992. Swine manure as a crop nutrient resource. In National livestock, poultry, and aquaculture waste management, ed. J. Blake, J. Donald, and W. Magette, 293-297. St. Joseph, Miss.: American Society of Agricultural Engineers. 